\title{
Nucleolar organizer regions, satellite associations and nucleoli of goat cells (Capra hircus)
}

\author{
KATARZYNA ANDRASZEK'ํㅡㄹ ELŻBIETA HOROSZEWICZ² and EŻBIETA SMALEC ${ }^{1}$ \\ 'Department of Animal Genetics and Horse Breeding, University of Podlasie, Siedlce, Poland, ${ }^{2}$ Department of \\ Breeding Methods and Poultry and Small Ruminant Breeding, University of Podlasie, Siedlce, Poland
}

\section{Abstract}

The Polish White Improved goat karyotype consists of 29 pairs of acrocentric autosomes, a large acrocentric $X$ chromosome and a metacentric $Y$ chromosome which is the smallest in the karyotype. Staining of chromosomes with $\mathrm{AgNO}_{3}$ solution has revealed active nucleolar organizer regions (NOR) in terminal parts of $q$ arms of pair 2, 3, 4, 5, and 28 chromosomes. Out of the total of 100 analysed cells 736 active NORs have been found, on average $7.4 \pm 0.2$ per cell. Active NORs were most frequently observed in pair 2 , and 3 chromosomes, most rarely on pair 5 chromosomes. In all the analysed cells 141 , satellite associations (SA) were observed, on average $1.4 \pm 0.2$ per cell. SAs most often occurred in cells with seven active NORs, and least often in cells with three or four nucleolar organizer regions. Most frequently in SAs the presence of pair 2, 3 and 28 chromosomes was observed. On meiotic chromosomes staining with $\mathrm{AgNO}_{3}$ solution revealed two nucleoli stained with different intensity. Both nucleoli in the cell were of similar size.

Keywords: goat, nucleolus, nucleolar organizer regions, meiotic chromosomes, satellite associations

\section{Zusammenfassung}

\section{Nukleolusorganisatorregionen, Satellitenassoziationen und Kernkörperchen der Hausziege (Capra hircus)}

Der Karyotyp der polnischen, weißen und veredelten Ziege besteht aus 29 Paaren der akrozentrischen Autosomen, aus einem großen akrozentrischen Chromosom $\mathrm{X}$ und aus dem metazentrischen Chromosom Y, dem kleinsten im Karyotyp.

Die Färbung der Chromosomen mit Hilfe von $\mathrm{AgNO}_{3}$-Lösung machte es möglich, aktive Nukleolusorganisatorregionen (NOR) an den terminalen Abschnitten q-Arms der Chromosomenpaare 2, 3, 4, 5, und 28 zu finden.

Unter den 100 analysierten Zellen wurden 736 aktive NORs gefunden, durchschnittlich 7,4 $\pm 0,2$ in einer Zelle. Aktive NORs wurden meistens auf den Chromosomen der Paare 2 und 3 beobachtet, am seltensten auf den Chromosomen des Paares 5. Unter den 100 analysierten Zellen wurden 141 Satellitenassoziationen (SA) entdeckt, durchschnittlich $1,4 \pm 0,2$ in einer Zelle.

SA treten meistens in den Zellen auf, die 7 aktive NORs enthalten, am seltensten jedoch in Zellen mit 3 oder 4 NOR. Es gibt meistens SA mit dem Anteil von Chromosomenpaaren 2 und 3 und auch 28. Durch die Behandlung der meiotischen 
Chromosomen mit Färbung mit Hilfe von $\mathrm{AgNO}_{3}$-Lösung nahmen 2 Kernkörperchen den Farbstoff verschieden stark an. Beide Kernkörperchen in der Zelle waren ähnlich groß.

Schlüsselwörter: Hausziege, Kernkörperchen, Nukleolusorganisatorregion, mitotische Chromosomen, Satellitenassoziationen

\section{Introduction}

In the genome of each higher organism species there are regions responsible for the structure and organization of nucleoli during the cell cycle. Nucleolar organizer regions (NORs) are parts of chromosomes in which there are ribosomal ribonucleic acid (rRNA) encoding genes $(5.8 \mathrm{~S}, 18 \mathrm{~S}, 28 \mathrm{~S})$. In all eukaryotic organisms rRNA genes occur in many copies thus reflecting high cell demand for rRNA (SUMMER 1990). The initial step in nucleolar formation is ribosomal gene transcription, which is mediated by RNA polymerase I (Pol I) and associated with transcription few factors such as upstream binding factor (UBF), selectivity factor (SL1) and transcription initiation factor (TIF-IA) (BODEM et al. 2000, MILLER et al. 2001).

NORs, as ribosomal gene clusters, that were active in previous interphase form prominent cytogenetic features, namely secondary constrictions. The main, defining characteristic of these constrictions is under-condensation in comparison with the rest of the chromosome. Genes encoding rRNA are associated with proteins UBF are characterised by silver-binding properties. In interphase the cell synthesizes nucleoli on the basis of rRNA genes (WEISENBERG and SCHEER 1995, MILLER et al. 2001).

The nucleolus is a comparatively large but, at the same time, the least stable cell structure. The nucleolus morphology and ultra structure change from species to species, and differ according to the cell type, the extent of cell differentiation and cell cycle. The size of nucleoli depends on the cell metabolic activity and it increases as the cells demand for ribosome's increases. The cells that do not intensively synthesize proteins, e.g. skeletal muscles, have got very small, almost atrophic nucleoli (WACHTLER et al. 1984, SOMMERVILLE 1985).

Epigenetic mechanisms active at the DNA methylation, and histone modification levels change the chromatin structure and control the reciprocal relation of active and inactive rRNA genes. Recent research has shown that the whole NORs or only some genes of nucleolar organizers can undergo silencing (GRUMMT and PIKAARD 2003).

The location and number of chromosomes on which NORs are situated vary in different species, and the regions can be situated in centromeric, terminal parts, or secondary constrictions (EVANS et al. 1964, HENDERSON et al. 1972, GOODPASTURE and BLOOM 1975, HENDERSON et al. 1976, HENDERSON and BRUERE 1980, MAYR et al. 1981, RICHER et al. 1990, SOLINAS TOLDO et al. 1992, MELLINK et al. 1994).

NOR location indicates frequent interactions between non-homologous chromosomes in centromeric regions (SUZUKI et al. 1990). Most probably they result from SAs. SAs follow from a reciprocal contact of acrocentric chromosomes by means of their short arms or the arms containing secondary constrictions (FERGUSON-SMITH and HANDMAKER 1961). SAs can be detected as single silver grains or bridges between NORs (MAYRWOHLFART et al. 1987). 
The polymorphism of association abilities was observed for each chromosome containing NOR, and a positive correlation of the frequency of SAs occurrence and the activity of nucleolar organizer regions (YIP and FOX 1981, SCHEER and HOCK 1999). The number and size of AgNOR deposits is a significant marker of the cell proliferative activity and DNA synthesis. The NOR activity in parenchymatic cells of high physiological activity, such as hepatocytes, is higher than in kidney cells of mesodermal origin (LEEK et al. 1991). Moreover, the relationship between the number of active NORs and rabbit's performance has also been observed (MAITESIAN 1990).

NORs, in regard to many species, are quite frequently explored and presented in the literature as well as SAs descriptions, whereas connection between NORs, SAs and nucleolous are single (ANDRASZEK and SMALEC 2007).

The objective of the work was to figure out the possible connection between the number of active NORs on chromosomes during mitosis and the number and size of nucleoli linked to meiotic chromosomes in goat cells and to trace the satellite chromosome associations.

\section{Material and methods}

The research examined mitotic chromosomes isolated from peripheral blood, and meiotic chromosomes isolated from nuclei of 7-month-old male goats of Polish White Improved breed. Material collected from ten animals was subjected to cytological analysis.

Mitotic chromosomes were isolated from an in vitro culture of peripheral blood by means of standard methods. Meiotic chromosomes were isolated according to the methodology described by EVANS et al. (1964). NORs on mitotic chromosomes and nucleoli on meiotic chromosomes were stained by the method of HOWELL and BLACK (1980). From each animal there were analysed 10 metaphase plates and 10 plates containing chromosomes in meiotic prophase I.

The NOR number and location, the number of satellite associations, and the proportion of individual chromosomes in mitotic chromosomes were examined. An identification of chromosomes with NORs and the chromosomes involved in SAs was done on the basis of their morphology and with reference to the standardized description of goat karyotype ISCNDB (2000). On meiotic chromosomes the number and size of the nucleoli present in prophase of meiotic division I were identified. The results obtained were statistically described.

\section{Results}

The Ag-NOR staining applied revealed active nucleolar organizer regions on mitotic chromosomes in different metaphase stages. Metaphase plates with chromosomes not divided into chromatids, typical of early metaphase, as well as chromosomes divided into chromatids typical of late metaphase were analysed. On chromosomes in subsequent metaphase stages, a NOR was visible in the form of two silver grains, one grain on each chromatid (Figure 1). 


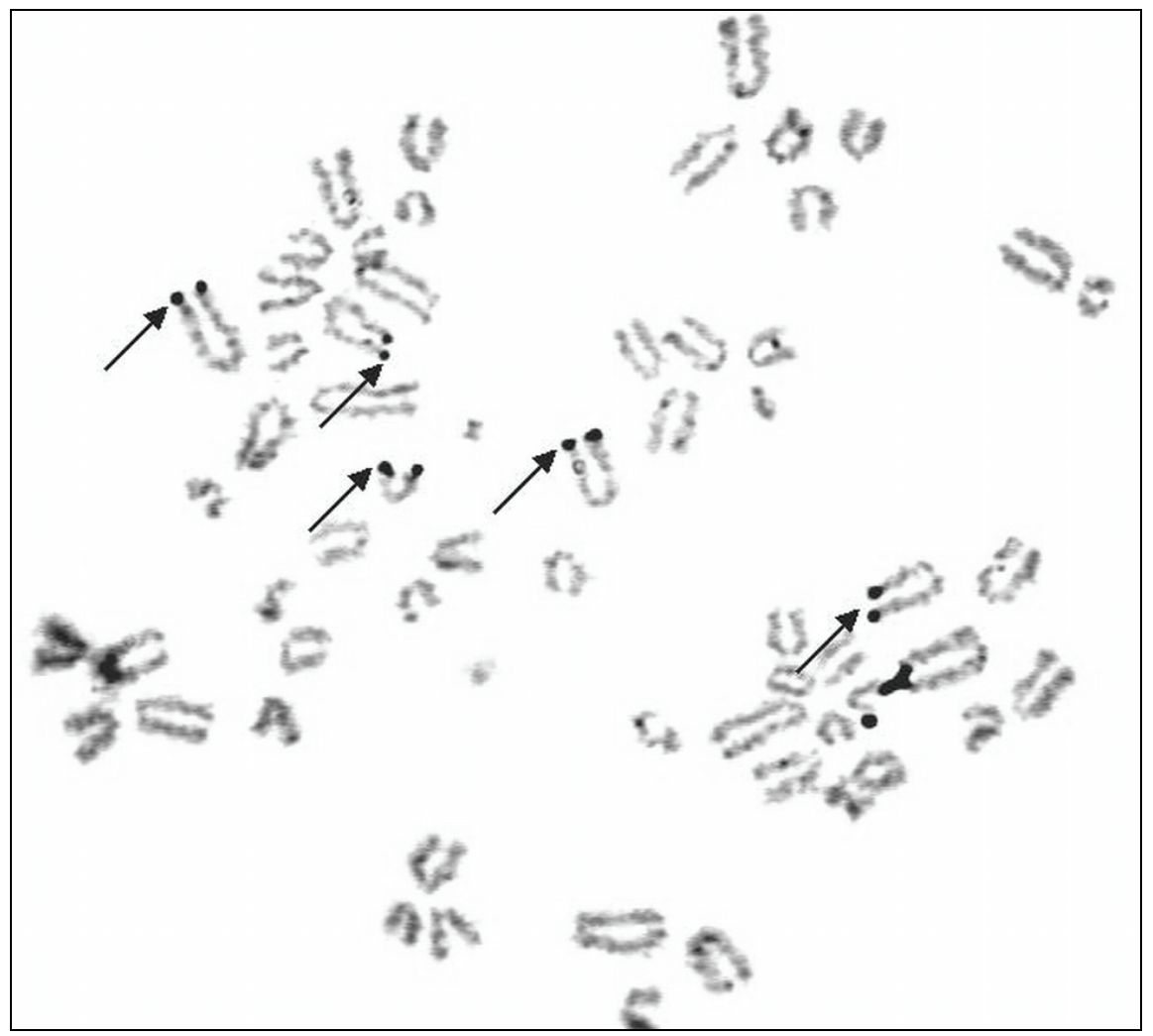

Figure 1

Mitotic chromosomes, late metaphase-NORs indicated by arrows

Mitotische Chromosomen, späte Metaphase. NORs werden mit Pfeilen gekennzeichnet.

Active NORs were found in terminal parts of $q$ arms of pair 2, 3, 4, 5 and 28 chromosomes. On average, in 10 analysed individuals, on the chromosomes of pair 2 there were observed $1.9 \pm 0.1$ spots with silver deposits, on pair 3 chromosomes $1.8 \pm 0.2$ spots, on pair 4 chromosomes $1.3 \pm 0.1$ spots, on pair 5 chromosomes $1.0 \pm 0.1$ spots and on pair 28 chromosomes $1.4 \pm 0.1$ spots with deposits of silver. In total, 736 active NORs were identified, 188 on pair 2 chromosomes, 179 on pair 3 chromosomes, 131 on pair 4 chromosomes, 96 on pair 5 chromosomes and 142 on pair 28 chromosomes. An average NOR number per cell in all the individuals equalled 7.4 \pm 0.2 . The NOR number in each examined individual was different and ranged from three to ten NORs per cell. Detailed results pertaining to an analysis of the NOR number and location in cells and in the individual, as well as statistic measures of the analysed parameters are presented in Table 1.

Chromosomes including NORs, in particular acrocentric chromosomes, tend to fuse and form satellite associations (SAs). Within 100 analysed cells 141 satellite associations, containing two or three chromosomes with active NOR, were found. The SAs number differed and ranged form 9 to 20 per individual and $1.4 \pm 0.2$ per cell (Table 2). Of 141 observed associations two-chromosome were 120 (average per cell 1.2 20.2 ) and 21 associations were formed by three chromosomes (average $0.2 \pm 0.2$ per cell). 
Table 1

NOR number in the cells of investigated animals

Anzahl der NOR in den Zellen der untersuchten Tiere

\begin{tabular}{lccccccc}
\hline & \multicolumn{9}{c}{ Number of NORs per chromosome } & \multicolumn{3}{c}{ Number of NORs per cell } \\
Animal & 2 & 3 & 4 & 5 & 28 & & \\
& $\overline{\mathrm{x}} \pm \mathrm{SD}$ & $\overline{\mathrm{x}} \pm \mathrm{SD}$ & $\overline{\mathrm{x}} \pm \mathrm{SD}$ & $\overline{\mathrm{x}} \pm \mathrm{SD}$ & $\overline{\mathrm{x}} \pm$ SD & $\overline{\mathrm{x}} \pm \mathrm{SD}$ & min-max \\
\hline 1 & $1.9 \pm 0.3$ & $1.5 \pm 0.7$ & $1.4 \pm 0.8$ & $1.1 \pm 0.9$ & $1.2 \pm 0.4$ & $7.1 \pm 2.0$ & $3-10$ \\
2 & $2.0 \pm 0.0$ & $1.7 \pm 0.5$ & $1.2 \pm 0.6$ & $0.8 \pm 0.6$ & $1.6 \pm 0.5$ & $7.3 \pm 1.5$ & $5-10$ \\
3 & $1.8 \pm 0.4$ & $1.9 \pm 0.3$ & $1.4 \pm 0.7$ & $1.3 \pm 0.7$ & $1.6 \pm 0.7$ & $8.0 \pm 1.7$ & $5-10$ \\
4 & $1.8 \pm 0.4$ & $1.8 \pm 0.4$ & $1.4 \pm 0.8$ & $1.1 \pm 0.7$ & $1.5 \pm 0.7$ & $7.6 \pm 2.0$ & $4-10$ \\
5 & $1.9 \pm 0.3$ & $1.6 \pm 0.5$ & $0.8 \pm 0.8$ & $0.3 \pm 0.5$ & $1.1 \pm 0.7$ & $5.7 \pm 1.6$ & $3-8$ \\
6 & $1.9 \pm 0.3$ & $1.9 \pm 0.3$ & $1.1 \pm 0.9$ & $0.7 \pm 0.8$ & $1.4 \pm 0.7$ & $7.0 \pm 1.6$ & $5-10$ \\
7 & $1.9 \pm 0.3$ & $2.0 \pm 0.0$ & $1.0 \pm 0.7$ & $0.4 \pm 0.7$ & $1.6 \pm 0.5$ & $6.9 \pm 1.4$ & $5-10$ \\
8 & $1.9 \pm 0.3$ & $1.9 \pm 0.3$ & $1.7 \pm 0.5$ & $1.3 \pm 0.8$ & $1.6 \pm 0.5$ & $8.4 \pm 1.8$ & $6-10$ \\
9 & $1.8 \pm 0.4$ & $1.7 \pm 0.5$ & $1.5 \pm 0.5$ & $1.4 \pm 0.7$ & $1.5 \pm 0.5$ & $7.9 \pm 1.8$ & $6-10$ \\
10 & $1.9 \pm 0.3$ & $1.9 \pm 0.3$ & $1.6 \pm 0.5$ & $1.2 \pm 0.8$ & $1.1 \pm 0.7$ & $7.7 \pm 1.5$ & $6-10$ \\
\hline
\end{tabular}

Table 2

Number and kind of SAs in the cells of examined animals

Art und Anzahl der SA in den Zellen der untersuchten Tiere

\begin{tabular}{|c|c|c|c|c|c|c|}
\hline \multirow{2}{*}{ Animal } & \multicolumn{2}{|c|}{ SAs-2 } & \multicolumn{2}{|c|}{ SAs-3 } & \multicolumn{2}{|c|}{ SAs } \\
\hline & $n$ & $\overline{\mathrm{x}} \pm \mathrm{SD}$ & $n$ & $\overline{\mathrm{x}} \pm \mathrm{SD}$ & $n$ & $\overline{\mathrm{x}} \pm \mathrm{SD}$ \\
\hline 1 & 9 & $1.2 \pm 0.9$ & 0 & $0.0 \pm 0.0$ & 9 & $0.9 \pm 0.9$ \\
\hline 2 & 13 & $1.2 \pm 0.9$ & 0 & $0.0 \pm 0.0$ & 13 & $1.3 \pm 0.9$ \\
\hline 3 & 8 & $1.2 \pm 0.9$ & 2 & $0.2 \pm 0.4$ & 10 & $1.0 \pm 0.9$ \\
\hline 4 & 11 & $1.2 \pm 0.9$ & 2 & $0.2 \pm 0.4$ & 13 & $1.3 \pm 0.8$ \\
\hline 5 & 10 & $1.2 \pm 0.7$ & 1 & $0.1 \pm 0.3$ & 11 & $1.1 \pm 0.6$ \\
\hline 6 & 11 & $1.2 \pm 0.8$ & 2 & $0.2 \pm 0.4$ & 13 & $1.3 \pm 0.8$ \\
\hline 7 & 10 & $1.2 \pm 0.8$ & 3 & $0.3 \pm 0.5$ & 13 & $1.3 \pm 0.5$ \\
\hline 8 & 17 & $1.2 \pm 0.9$ & 3 & $0.3 \pm 0.5$ & 20 & $2.0 \pm 0.9$ \\
\hline 9 & 15 & $1.2 \pm 0.5$ & 4 & $0.4 \pm 0.5$ & 19 & $1.9 \pm 0.9$ \\
\hline 10 & 16 & $1.2 \pm 0.5$ & 4 & $0.4 \pm 0.5$ & 20 & $2.0 \pm 0.7$ \\
\hline
\end{tabular}

SAs-2 two-chromosome associations, SAs-3 three-chromosome associations, SAs total number of associations

On the basis of an analysis of the number of associations, according to the NOR number in the goats cell, it was found, that SAs most frequently occurred in cells containing seven active NORs and the least frequently in the cells with three or four nucleolar organizer regions. Also, the proportion of cells in which SAs were found varied. Out of 100 cells subjected to analysis, most often cells with one satellite association were detected, the cells with three SAs being found occasionally (Table 3). Figure 2 shows metaphase plates with different number and type of satellite associations.

Table 3

SAs presence according to the NOR number in the cell SA-Vorkommen je nach NOR-Anzahl in einer Zelle

\begin{tabular}{lrrrrrrrrr}
\hline \multirow{2}{*}{ Number of SAs per cell } & \multicolumn{1}{c}{ Number of NORs per cell } \\
& 3 & 4 & 5 & 6 & 7 & 8 & 9 & 10 & total \\
\hline 0 & 1 & 3 & 2 & 8 & 5 & 0 & 0 & 2 & 21 \\
1 & 1 & 1 & 3 & 5 & 15 & 7 & 6 & 1 & 39 \\
2 & 0 & 0 & 5 & 2 & 6 & 8 & 4 & 9 & 34 \\
3 & 0 & 0 & 0 & 0 & 0 & 1 & 1 & 4 & 6 \\
Total & 2 & 4 & 10 & 15 & 26 & 16 & 11 & 16 & 100 \\
\hline
\end{tabular}




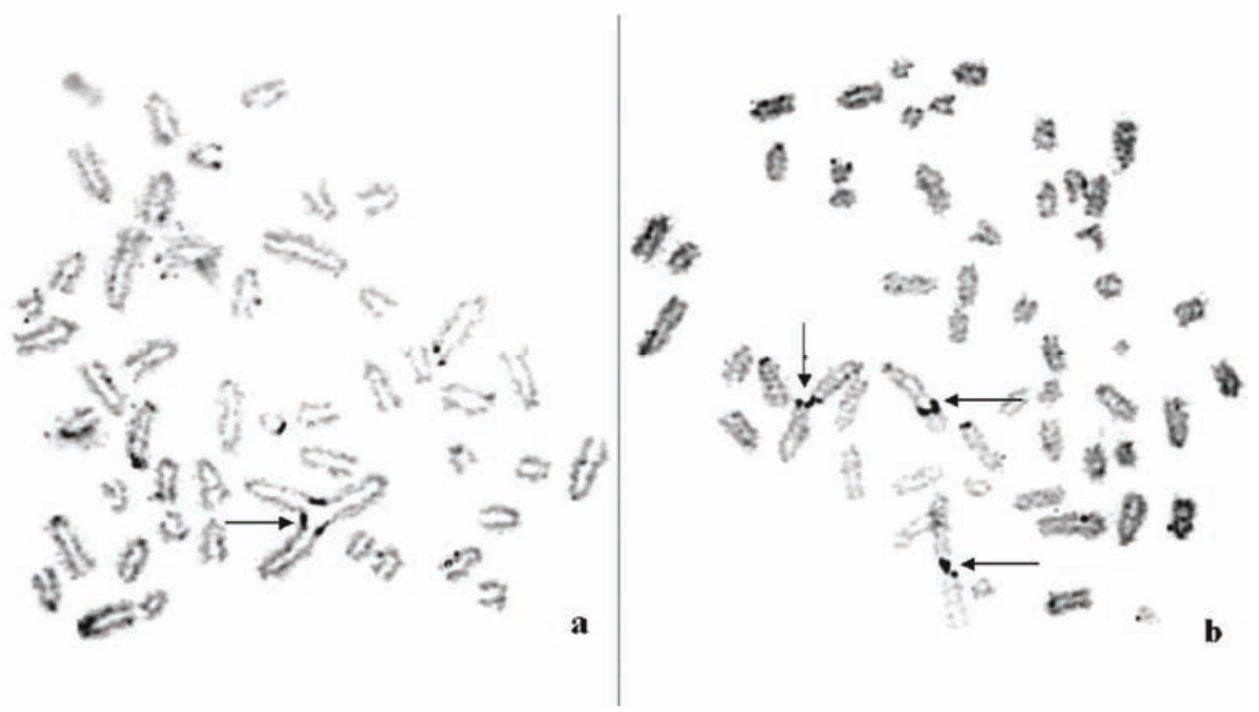

Figure 2

A metaphase cell with one three-chromosome association (a) and three two-chromosome associations (b). SAs indicated by arrows.

Metaphaseplatte mit einer Assoziation von drei Chromosomen (a) und mit drei Assoziationen von zwei Chromosomen (b). SA werden mit Pfeilen gekennzeichnet.

Moreover, tendencies of particular chromosome pairs to form satellite associations varied. Most often the presence of pair 2, 3, and 28 chromosomes was observed in SAs. This tendency was found within two- and three-chromosome forming SAs. Also, reciprocal associations of individual chromosomes differed. Most frequently, there were associated large chromosomes of pair 2 and 3, as well as pair 2 and 3 chromosomes with pair 28 chromosomes. However, no SAs including pair 3 and 4 chromosomes were found. Table 4 presents the share of chromosomes of individual pairs in SAs.

Table 4

Share of chromosomes in SAs

Chromosomenanteil in den $S A$

\begin{tabular}{lcr}
\hline SAs type & Share of chromosomes & Number of associations \\
\hline & $2 \leftrightarrow 3$ & 47 \\
$2 \leftrightarrow 4$ & 5 \\
$2 \leftrightarrow 5$ & 2 \\
$2 \leftrightarrow 28$ & 22 \\
$3 \leftrightarrow 4$ & 3 \\
$3 \leftrightarrow 28$ & 10 \\
$4 \leftrightarrow 5$ & 9 \\
$4 \leftrightarrow 28$ & 6 \\
SAs-2 & $5 \leftrightarrow 28$ & 12 \\
& $28 \leftrightarrow 28$ & 5 \\
& $2 \leftrightarrow 3 \leftrightarrow 3$ & 7 \\
$2 \leftrightarrow 3 \leftrightarrow 4$ & 3 \\
& $2 \leftrightarrow 3 \leftrightarrow 28$ & 10 \\
\hline
\end{tabular}

SAs-2 two-chromosome associations, SAs-3 three-chromosome associations 
On meiotic chromosomes silver nitrate staining revealed nucleoli in the cells in different stages of prophase of meiotic division I. Analysis was carried out on chromosomes which were long looped strands typical of early prophase, and on emerging bivalents observed in subsequent phases of prophase of meiotic division I. In all the analysed cells two nucleoli were observed, one being stained more intensively than the other (Figure 3). Both nucleoli in the cell were of similar size.

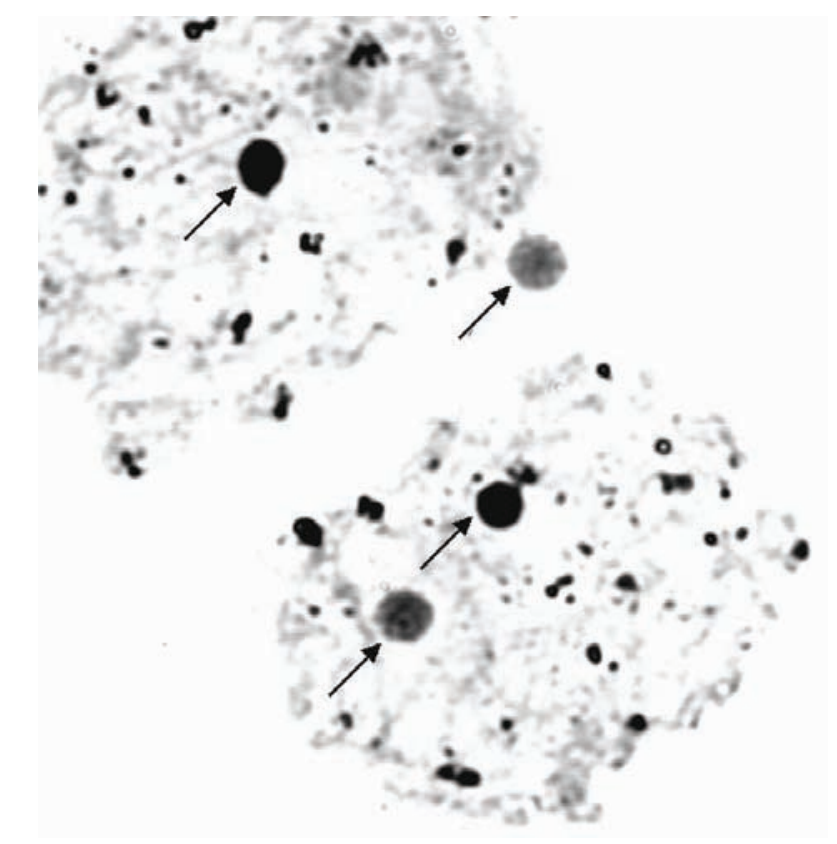

Figure 3

Differently stained nucleoli

Mit verschiedener Intensität ausgefärbte Kernkörperchen

\section{Discussion}

The goat karyotype obtained in the current work consisted of 29 large acrocentric autosomes, a large acrocentric $X$ chromosome and a metacentric $Y$ chromosome which was the smallest in the karyotype. It meets the karyotype standards for Capra hircus (ISCNDB 2000). Active nucleolar organizer regions were identified on pair 2, 3, 4, 5, and 28 chromosomes. All identified NORs occurred in the terminal parts of $q$ arms of chromosomes. Results of present study support ISCNDB (2000) in regard to goat chromosomes. On cattle chromosomes NORs are also found in telomeres and they occur in analogous to goat chromosomes 2, 3, 4 and on pair 11 and 25 chromosomes (ISCNDB, 2000).

NORs occur with various frequency on particular chromosomal pairs- more often on number 2, 3 and 28 chromosome pairs and occasionally on the 5 pair, moreover often on one of homologues of goat chromosomes. MAYR et al. $(1987,1989)$ observed similar to our results discrepancies for cattle chromosomes.

It is assumed that the number of stained NORs in mitosis depends on the rand transcription activity. It is supposed that only NORs in which transcription will take place 
in the next cell cycle are stained, the others not (BABU and VERMA 1995, WEISENBERG and SCHEER 1995, BABU et al. 2005). Moreover, in the metaphase of one and the same individual there exists inter-cell differentiation of NOR expression with respect to the number, size and staining intensity of silver deposits. Variability of the number and size of NORs on the cell and ontogenetic level has also been observed in cattle (DI BERARDINO et al. 1985; MAYR et al. 1987), horse (KOOP et al. 1981) and sheep (DI MEO et al. 1993). Chromosomes that included NOR, particularly acrocentric ones, show tendency to fuse with each other and form the so-called satellite associations. DI BERARDINO et al. (1981) investigations showed, that the correlation between the number of NORs and the number od SAs was not statistically significant for most of the individuals.

In the present work an analysis of the number of chromosomes participating in SAs showed that the highest was the proportion of two-chromosome associations. DI BERARDINO et al. (1981) reported that the most frequent types of nucleolar associations in two Bovidae species involved two chromosomes (acrocentric-short arm of submetacentric and acrocentric-acrocentric) while those involving three or four chromosomes were less frequent. In studies on goats (MORENO MILLAN and RODERO FRANGANILLO 1988) it has been suggested that the phenomenon of chromosomes entering associations is an individual characteristic, and despite the fact that in goats there are found two-, threeand four-chromosome, most often two-chromosome associations dominate. The results presented in the current paper may support this suggestion.

The number of NORs in the work discussed ranged from 3 to 10 per cell whereas the SAs number was the highest in the cells with 7 active NORs. DI BERARDINO et al. (1981), in their studies on domestic cattle and buffalo, obtained the NOR number ranging from 3 to 10 , the SAs number detected being the largest in the cells with 6 active NORs.

Works pertaining to the number and size of nucleoli in meiosis and their connection with the number of NORs active in mitosis can be sporadically found in the literature. Such research, extended to include attempts to assign nucleoli to specific bivalents, has been carried out in swine. However, in the above-mentioned study a different number and size of nucleoli in cells have been observed (SŁOTA 1998). In contrast, in domestic goose cells from one to four nucleoli of different size have been recorded, most cells having 1 or 2 nucleoli (ANDRASZEK and SMALEC 2007).

The comparison of the number of stained nucleoli obtained in the study with the number of active NORs in the cell has revealed that the nucleoli number in the cells of examined goats was constant and independent on the number of NORs stained. This lack of relationship may be explained by the fact that NORs situated on different chromosomes may participate in formation of one nucleolus (FERGUSON-SMITH and HANDMAKER 1961, 1963, WALKER and PACE 1983, WACHTLER et al. 1984).

No papers were found in the literature on diverse intensity of nucleoli staining within one and the same cell. It is possible that the causes underlying this phenomenon depend on transcription activity of rRNA genes and differences in the size and number of active NORs connected with it. A more darkly stained nucleolus is likely to form NORs of associated chromosomes. However, the present stage of research allows such a conclusion to be only an assumption. 


\section{References}

Andraszek K, Smalec E (2007) Number and size of nucleoli in the spermatocytes of European domestic goose (Anser anser). Arch Geflügelk 71, 237-40

Babu KA, Verma RS (1985) Structural and functional aspects of nucleolar organizer regions (NORs) in human chromosomes. Int Rev Cytol 94, 151-76

Babu V, Rao Ghosh K, Mohanty D (2005) Nucleolar organising region evaluation using new NOR FISH probe. Ind Jour Hum Genet 11, 44-6

Bodem J, Dobreva G, Hoffmann-Rohrer U, Iben S, Zentgraf H, Delius H, Vingron M, Grummt I (2000) TIF-IA the factor mediating growth-dependent control of ribosomal RNA synthesis is the mammalian homolog of yeast Rrn3p. EMBO Reports 1, 171-5

Di Berardino D, lannuzzi L, Bettini TM, Matassino D (1981) Ag-NORs variation and banding homologies in two species of Bovidae Bubalus bubalis and Bos taurus. Can J Genet Cytol 23, 89-99

Di Berardino D, lannuzzi L, Lioi MB (1985) The high-resolution RBA-banding pattern of bovine chromosomes. Cytogenet Cell Genet 39, 136-9

Di Berardino D, Burguete I (1998) High resolution RBA-banding comparison between early prometaphase chromosomes of cattle (Bos taurus L) and goat (Capra hircus L) at 700 band level. Cytogenet Cell Genet 83, 130-8

Di Meo GP, lannuzzi L, Perucatti A, Ferrara L (1993) Identyfication of nucleolus organizer chromosomes in sheep (Ovis aries $L$ ) by sequentical GTG Ag-NOR and RBG Ag-NOR techniques. Cytobios 75, 302-3

Evans EP, Breckon G, Ford CE (1964) An air-drying method for meiotic preparation from mammalian testes Cytogenet 3, 295-8

Ferguson-Smith MA, Handmaker SD (1961) Observations on satellited human chromosomes. Lancet 1, 638-40

Ferguson-Smith MA, Handmaker SD (1963) The association of satellited chromosomes with specific chromosomal regions in cultured human somatic cell. Ann Hum Genet 27, 143-55

Goodpasture C, Bloom SE (1975) Visualization of nucleolar organiser regions in mammalian chromosomes using silver staining. Chromosoma 53, 37-50

Grummt I, Pikaard CS (2003) Epigenetic silencing of RNA polymerase I transcription. Nat Rev Mol Cell Biol 4, 641-9

Henderson A, Bruere A (1980) Inheritance of Ag-stainability of the nucleolus organizer regions in domestic sheep Ovis aries. Cytogenet Cell Genet 26, 1-6

Henderson A, Warburton D, Atwood K (1972) Location of ribosomal DNA in the human chromosome complement. Proc Nat Acad Sci 69, 3394-8

Henderson A, Eicher E, Yu M, Atwood K (1976) Variation in ribosomal RNA gene number in mouse chromosomes. Cytogenet Cell Genet 17, 307-16

Howell WM, Black DA (1980) Controlled silver-staining of nucleolus organizer regions with a protective colloidal developer a 1-step method. Experentia 36, 1014-5

ISCNDB (2000) International System for Chromosome Nomenclature of Domestic Bovids. Cytogenet Cell Genet 92, 283-99

Kopp E, Mayr B, Czaker R, Schleger W (1981) Nucleus organizer regions in the chromosomes of the domestic horse. J Hered 72, 357-8

Leek RD, Alison MR, Sarraf CE (1991) Variations in the occurence of silver-stained nucleolar organizer regions (Ag-NORs) in non proliferating and proliferating tissues. J Pathol 165, 43-51

Maitesian ES (1990) Polymorphism of Nucleolus in the Cells of Different Ploidy. 9th European Colloquium on cytogenetics of Domestic Animals 32

Mayr B, Vogel I, Schleger W (1981) The silver-staining technique-a tool for characterizing lymphocyte populations in mammalian peripheral blood. Cell Mol Life Sci 37, 1343-4

Mayr B, Schleger W, Auer H (1987) Frequency of Ag-stained nucleolus organizer regions in the chromosomes of cattle. J Hered 78, 206-7

Mayr B, Gruber K, Brem G, Mayrhofer G (1989) Genetic studies on nucleolus organizer regions (NORs) in cattle. Genet Res 53, 111-8

Mayr-Wohlfart U, Adolph S, Klett C, Hameister H (1987) Metaphase association of mammalian chromosomes. Genome 29, 807-10 
Mellink CHM, Bosma AA, De Hann NA (1994) Variation in the sise of Ag-NORs and fluorescent rDNA in situ hybridisation signals in six breeds ofdomestic pig. Hereditas 120, 141-9

Miller G, Panov KI, Friedrich JK, Trinkle-Mulcahy L, Lamond Al, Zomerdijk JC (2001) hRRN3 is essential in the SL1-mediated recruitment of RNA Polymerase I to rRNA gene promoters. EMBO J 20, 1373-82

Moreno Millan M, Rodero Franganillo A (1988) NOR-association patterns in Goat chromosomes. 8th European Colloquium on Cytogenetics of Domestic Animals 83

Richer CL, Power MM, Klunder LR, Mc Feely AR, Kent MG (1990) Standard Karyotype Of Domestic Horse (Equus caballus). Hereditas 112, 289-93

Roussel P, Hernandez-Verdun D (1994) Identification of Ag-NOR proteins markers of proliferation related to ribosomal gene activity. Exp Cell Res 214, 465-72

Scheer U, Hock R (1999) Structure and function of the nucleolus. Curr Opin Cell Biol 11, 385-90

Słota E (1998) Chromosome polymorphism in swine. Rocz Nauk Zoot Instytut Zootechniki Kraków Diss 7 , 1-58 [in Polish]

Solinas Toldo S, Pieńkowska A, Fries R Świtoński M (1992) Localization of nucleolar organizer regions in farm animals by in situ hybrydization method with a probe froma human rRNA gene. European Colloquium on Cytogenetics of Domestic Animals, 228-31

Sommerville J (1985) Organizing the nucleuolus. Nature 318, 410-1

Suzuki H, Kurihara Y, Kanehisa T, Moriwaki K (1990) Variation in the distribution of silver staining nucleolar organizer regions on the chromosomes of the wild mouse Mus musculus. Mol Biol Evol 7, 271-82

Wachtler F, Schwarzacher HG, Smetana K (1984) On the fusion of nucleoli in interphase. Eur J Cell Biol 34, 190-2

Walker TA, Pace NR (1983) 58 S ribosomal RNA. Cell 33, 320-2

Weisenberger D, Scheer U (1995) A possible mechanism for the inhibition of ribosomal RNA gene transcription during mitosis. J Cell Biol 129, 561-75

Yip MY, Fox DP (1981) Correlations between relatives for acrocentric association frequency. Hum Genet $59,245-9$

Received 6 June 2008, accepted 5 January 2009.

Corresponding author:

Dr inż. KATARZYNA ANDRASZEK

email: andrasz@ap.siedlce.pl

Department of Animal Genetics and Horse Breeding, Institute of Bioengineering and Animal Breeding, University of Podlasie, ul. B. Prusa 14, 08-110 Siedlce, Poland 